Complutense Journal of English Studies

ISSN: 2386-3935

\title{
Enhancing L2 Motivation and English Proficiency through Technology
}

\author{
Flordelis González Mujico \& David Lasagabaster ${ }^{1}$
}

\begin{abstract}
Balancing and mastering the linguistic and academic demands of English teaching in higher education can become a difficult hurdle to surpass. Since curricula that integrates technology appears to provide an array of opportunities that promote engagement and language skills, it is worth examining how and whether L2 motivation, self-regulation and learning can be heightened through digital technologies. This paper describes a 6-week intervention programme conducted on 205 international students enrolled on an English for Academic Purposes course at a British university. Based on L2 imagery techniques and ePortfolios, the intervention proved to be of benefit to learner engagement and language acquisition.
\end{abstract}

Keywords: electronic portfolios, English for academic purposes, L2 motivation, self-regulation.

\section{[es] El fomento de la motivación y del aprendizaje del inglés mediante la tecnología}

Resumen. Las exigencias lingüísticas y académicas de la enseñanza del inglés en la educación superior pueden convertirse en un obstáculo difícil de superar. Dado que el currículo que integra la tecnología parece proporcionar una serie de oportunidades que promueven el compromiso y las habilidades lingüísticas, es preciso examinar si la motivación, la autorregulación y el aprendizaje de una L2 se pueden aumentar a través de las tecnologías digitales. Este artículo describe una intervención de 6 semanas realizada en la que participaron 205 estudiantes de inglés para fines específicos de una universidad británica. Empleando técnicas de visualización de la L2 y portafolios digitales, la intervención demostró ser beneficiosa para la participación estudiantil y la adquisición del inglés.

Palabras clave: Autorregulación, Inglés para fines específicos, Motivación, Portafolios digitales.

Contents. 1. Introduction. 2. Literature review. 3. Research question. 4. Methodology. 4.1. Sample. 4.2. Instruments. 4.3. Data Collection and Analysis. 5. Results. 5.1. Quantitative Findings. 5.2. Qualitative Findings. 6. Discussion and final conclusions.

How to cite this article: González Mujico, F.; Lasagabaster, D. (2019) Enhancing L2 Motivation and English Proficiency through Technology, in Complutense Journal of English Studies 27, 59-78.

\section{Introduction}

English for Academic Purposes (EAP) instruction aims to provide students with the linguistic and academic practices involved in studying through the medium of English. Most higher education institutions in the UK offer EAP courses to current and

1 Department of English Studies, University of the Basque Country (UPH/EHU), fgonzalez015@ikasle.ehu.eus / david.lasagabaster@ehu.eus. 
prospective students who study or want to undertake undergraduate or postgraduate study in their institution, but do not have the language level requirement of English. EAP provides a fertile context in which to examine the influence of L2 motivation and self-regulation as the academic workload can be both complex and intensive. Consequently, students struggle to maintain focus and momentum as learning thresholds are challenged both linguistically and academically.

Motivation has consistently been shown to be a major factor in explaining learner success in L2 acquisition (Dörnyei 2009). It is widely recognised as a significant variable in human learning that affects goals and directions pursued, levels of effort invested, depth of engagement, and degree of persistence in learning (Ushioda 2014). An association is generally assumed in the literature between the concepts of motivation and self-regulation, the most recent being the L2 Motivational Self System (L2MSS) proposed by Dörnyei (2009) and centred on possible selves. Markus and Nurius (1986) propose one of the most powerful mechanisms to describe how the self regulates behaviour by setting goals and expectations through their concept of 'possible selves', which they define as the ideal selves that we would very much like to become, the selves we could become and the selves we are afraid of becoming (Markus and Nurius 1986: 954). Through the selection and construction of possible selves, individuals can be viewed as active producers of their own development and conceptualisation of their as-yet unrealised potential, drawing upon their hopes, wishes and dreams. In this sense, possible selves function as future self-guides that shed light on how individuals are moved from the present towards the future, forming an explicit link between the current self-system and self-regulated behaviour (Dörnyei and Ushioda 2009).

For these future self-guides to be effective, they need to come as part of a package that comprises an imagery component and a repertoire of appropriate plans, scripts and self-regulatory strategies (Dörnyei 2009: 21). The use of portfolios has been broadly discussed and praised in relation to identity construal, self-assessment and goal attainment in education (Barrett 2009), all of which support the aims of future self-guides. Established as a field of research within the wider field of portfolio research is the electronic portfolio or ePortfolio. A system that may serve to deepen students' learning experiences by scaffolding essential metacognitive skills such as goal setting, identifying strategies, and reflecting on one's learning (Abrami Venkatesh Meyer and Wade 2013) in a manner that parallels their digital understanding of the universe. It is on this premise that studies (e.g., Attwell 2007; Barrett 2009; Meyer et al. 2010) recommend that ePortfolios be used as personal learning environments or to represent one's digital identity of the 21 st century, which would also extend to the construction of L2 possible selves.

To test this assumption, this paper presents a mixed-methods investigation on the influence of ePortfolios and L2 possible selves in a higher education EAP context through a learner-centred intervention programme. The focus of this study will be on the impact of an ePortfolio intervention in relation to the sustainability of L2 motivation, self-regulation and L2 learning based on the digital construction of possible selves. After a brief literature review, the research questions, analytical framework and methodology of the study are presented. This is followed by the analyses of quantitative and qualitative data, wherein the results will be linked to patterns highlighted in the literature review. A conclusion of the study's findings is presented at the end along with the limitations of the research design employed. 


\section{Literature review}

Although there are good theoretical reasons to suppose that self-regulated and motivated learners are better language learners, further empirical evidence is needed to corroborate experience-based intuitions and under what circumstances these dispositions heighten L2 development. For over five decades, motivation has been a major research topic within L2 acquisition, stemming from a need to uncover the conditions that facilitate the learning of a new language. One of the most recent approaches to broaden the L2 motivation construct is the L2MSS (Dörnyei 2009). Based on the concepts of 'possible selves' from social psychology (Markus and Nurius 1986) and 'self-discrepancy theory' (Higgins 1987), the L2MSS (Dörnyei 2009) comprises the L2 language experience and two aspects of the learner's self-concept: the Ideal L2 self (a representation of the L2 attributes a learner wishes to possess if able to master the L2), and the ought-to L2 self (a representation of the attributes a learner believes they should or ought to possess, generally connoting a sense of duty, obligations, or responsibilities). Discrepancy between these selves and the actual self initiates motivation and self-regulatory strategies in an attempt to reduce this chasm (Higgins 1987). Within future self-guides, the Ideal L2 self is ascribed a promotional focus based on the learner's hopes, while ought self-guides are assigned a preventive focus that regulates the absence or presence of negative outcomes.

To translate the motivational and self-regulatory potential of future self-guides into action, certain conditions must be met (Oyserman Bybee and Terry 2006). First, the learner needs to have a roadmap of tasks and strategies to follow in order to approximate an L2 possible self. Second, the secret of a successful learner is their possession of a superordinate vision that keeps them on track and grounded (Dörnyei 2009). Future self-guides are attained and sustained only when anchored in a sense of realistic expectation, referred to as plausibility. To achieve these outcomes, successful applications of imagery techniques have been reported in various educational contexts. Several studies have corroborated how these strategies can enhance learners' future identities and their academic learning motivation (e.g., Oyserman et al. 2006; Sheldon and Lyubomirsky 2006).

In an L2 educational context, there have been various successful intervention studies integrating mental imagery to L2 learning contexts through various techniques such as mental simulations, guided and scripted imagery. In comparing the effects of imagery and verbal processing, these studies have revealed that imagery can greatly influence learners' affect, as imagery not only influences human emotion but also cognition, and that learners' Ideal L2 selves are positively associated with both visual and auditory components of imagery (Dörnyei and Chan 2013; Kim and Kim 2011). Overall, the results (e.g., Magid 2014; Murray 2013) suggest that imagery plays a key role in the development of L2 future self-guides, and that learners with a vivid L2 self-image, in which imagery is an integral component, are more likely to be motivated and to take actions in language learning.

Asian students have been the primary focus in a number of possible selves intervention studies employing imagery techniques, as is the case in this study. Magid (2014) was the first to successfully apply the L2MSS using scripted imagery at a British university in China. The results of his intervention reported that learners wanted to devote more time and effort to learning English, while they developed positive communication skills, active listening, and their vocabulary expanded. Sub- 
sequent studies (e.g., Dörnyei and Chan 2013; Sampson 2012) corroborated these significant associations between learners' future self-guides and intended effort and actual grades among Asian learners. Despite studying under two different programme conditions, in two different locations, England and Hong Kong, Magid and Chan (2012) also found that both intervention programmes increased motivation and linguistic self-confidence among Chinese learners of English by strengthening their vision of their Ideal L2 self and making their goals clearer and more specific. However, the question remains as to whether these benefits can be enhanced in an L2 educational context through digital technologies, as the use of ePortfolios is on the increase, but there are still few research studies on their impact on the learning of English as an L2.

Electronic portfolios are digital tools that differ from general portfolios in that they build on the evidence of what is already known about effective portfolio pedagogy. They can be used as a learning tool that organises content through a selection of digital containers that can store visual and auditory content, including text, images, video, and sound, while their design supports a variety of pedagogical processes and assessment purposes (Barrett 2009). Applying this type of multimodal environment to L2 possible selves would appeal to a larger number of students given its ability to project a number of learning styles, i.e. visual learners who respond to images and graphics, auditory learners who prefer verbal presentations, and kinaesthetic learners who prefer a physical, hands-on approach. Although attempts to theorise and classify these learning styles remain a moot point, what does appear likely is that learners have certain preferences for different pedagogic approaches in varying contexts. In this sense, Attwell (2007) argues that despite the partiality of educational software to either heighten or restrain certain learning approaches, dependent on the design and process of use, an ePortfolio can allow learners to configure and develop a learning environment to suit and enable their own style of learning based on a variety of styles, i.e. visual, auditory and kinaesthetic. By the same token, learners would be able to reflect continually upon their academic objectives and progress through a familiar context that mirrors their everyday employment of digital technologies and visual content, which might enhance the overall impact and visualisation of future self-guides.

To date, studies (e.g., Cheng 2008) have been conducted on the challenges of ePortfolio curriculum implementation in English language teaching, while others (e.g., Abrami et al. 2013; Meyer et al. 2010) have examined ePortfolio implementation in relation to self-regulation and overall academic achievement. These studies reported that students enjoyed using the software, especially the personalisation that allowed learners to take ownership, while the degree of implementation had a positive impact on self-regulation, literacy achievement, and approaches to teaching and integrating technologies in the classroom. Although these findings render convincing evidence that ePortfolios can have a meaningful impact on learning when wisely and well implemented in the classroom, they do not provide empirical evidence of their benefits in an L2 educational context. For this reason, it is worth examining whether integrating a theoretical framework of L2 possible selves based on imagery techniques within a curricular ePortfolio would enhance L2 motivation, self-regulation and learning outcomes in the L2 classroom. In doing so, this study can expand on the unilateral account offered to date in these studies, providing a panoptic survey of L2 possible selves, imagery techniques and ePortfolios in an L2 setting. 
This brief review of the literature presents the theoretical background and reasoning that underpin the application of L2 possible selves based on imagery techniques through ePortfolios. Inasmuch as visualisation techniques have proved beneficial to L2 motivation, self-regulation and learning outcomes, further clarity is required on whether these outcomes can be enhanced through digital technologies. To explore this exact point will be the aim of this study.

\section{Research question}

Extant research underscores the prominent role of applying imagery techniques to possible selves in order to enhance L2 motivation, self-regulation and acquisition. In the current era of living in a highly technologized world, it is worthwhile examining whether these effects can be enhanced through the application of electronic portfolios. With this in mind, this study entertained the following research question: can L2 possible selves based on imagery strategies and constructed through ePortfolios increase L2 motivation, self-regulation and language outcomes among EAP learners?

\section{Methodology}

In order to test the effects of L2 possible selves, imagery strategies and ePortfolios, this study used a mixed-methods design employing questionnaires and focus group interviews. Significant statistical trends were identified in the quantitative data first, the possible causes of which were pursued through interviews with a smaller number of participants to provide a broader picture of the issues under investigation (Dörnyei and Ushioda 2011: 62).

\subsection{Sample}

A sample of 205 undergraduate students who enrolled in an EAP course at a British university agreed to participate in this study. The majority of participants were aged between 20 and $25(93 \%)$ and were of Chinese nationality $(97 \%)$, with an average IELTS level 5 across the board in all skills (reading, writing, listening and speaking). Nine out of ten participants (91\%) did not speak an additional L2 to their L1 aside from English. In order to increase the validity of the experiment, a control group was included. The sample of students was divided as follows: 120 experimental students (58\%) and 85 control participants $(42 \%)$. Groups were fairly homogeneous in regard to age, gender, nationality and L2 background (table 1). Students were randomly assigned to either an experimental group, made up of ten classes and ten teachers, or to a control group, composed of seven groups and seven teachers. All 17 teachers had previous experience teaching English as an L2, with the majority of them having taught English for over five years. Most teachers $(80 \%)$ had previous experience imparting EAP courses in higher education. 
Table 1. Student sample gender, age, nationality and L2 background.

\begin{tabular}{|c|c|c|c|c|c|c|c|}
\hline & & \multicolumn{2}{|c|}{ Experimental } & \multicolumn{2}{|c|}{ Control } & \multicolumn{2}{|c|}{ Entire Sample } \\
\hline & & $\mathbf{N}$ & $\%$ & $\mathbf{N}$ & $\%$ & $\mathbf{N}$ & $\%$ \\
\hline \multirow[t]{2}{*}{ Gender } & Male & 44 & $37 \%$ & 33 & $39 \%$ & 77 & $38 \%$ \\
\hline & Female & 76 & $63 \%$ & 52 & $61 \%$ & 128 & $62 \%$ \\
\hline \multirow[t]{4}{*}{ Age } & Under 20 & 5 & $4 \%$ & 6 & $7 \%$ & 11 & $5 \%$ \\
\hline & Between 20 and 25 & 114 & $95 \%$ & 77 & $91 \%$ & 191 & $93 \%$ \\
\hline & From 26 to 30 & 0 & $0 \%$ & 1 & $1 \%$ & 1 & $1 \%$ \\
\hline & Over 30 & 1 & $1 \%$ & 1 & $1 \%$ & 2 & $1 \%$ \\
\hline \multirow[t]{2}{*}{ Nationality } & Chinese & 117 & $98 \%$ & 82 & $97 \%$ & 199 & $97 \%$ \\
\hline & Asian other & 3 & $2 \%$ & 3 & $3 \%$ & 6 & $3 \%$ \\
\hline \multirow[t]{3}{*}{ L2s } & No additional L2 & 109 & $91 \%$ & 77 & $91 \%$ & 186 & $91 \%$ \\
\hline & Additional L2 & 11 & $9 \%$ & 8 & $9 \%$ & 19 & $9 \%$ \\
\hline & & Mean & SD & Mean & SD & Mean & SD \\
\hline \multirow[t]{4}{*}{ IELTS level } & Reading & 5.27 & 0.62 & 5.24 & 0.59 & 5.26 & 0.61 \\
\hline & Listening & 5.17 & 0.57 & 5.20 & 0.59 & 5.18 & 0.57 \\
\hline & Writing & 5.07 & 0.48 & 5.09 & 0.50 & 5.08 & 0.49 \\
\hline & Speaking & 5.07 & 0.49 & 5.07 & 0.56 & 5.07 & 0.52 \\
\hline
\end{tabular}

\subsection{Instruments}

The quantitative part of the study was based on data collected through a questionnaire that measured learner motivation and self-regulation, while L2 acquisition gains were measured through EAP summative course assessments. Participants filled out the motivation questionnaire, which consisted of three parts and 51 items. Participants had to answer closed questions with 6-point Likert scales, ranging from 1 (strongly agree) to 6 (strongly disagree). Parts 1 and 2 comprised 51 items that assessed motivation and self-regulation. Learner motivation was assessed using the L2MSS scale and additional items taken from scales validated in previous studies (Abrami et al. 2013; Asker 2012; Dafei 2007; Dörnyei and Chan 2013; Hung 2015; Iwaniec 2014; Taguchi Magid and Papi 2009; Teng and Zhang 2016; Waller and Papi 2017; You and Dörnyei 2016). In total, 40 items measured a total of eight motivational traits: criterion measures (e.g., "I am prepared to invest a lot of time on improving my English"), Ideal L2 self (e.g., "when I think of my future career, I can imagine myself using English"), ought-to self (e.g., "my parents believe that I must study English to be an educated person"), instrumentality promotion (e.g., "I will be able to make a lot of money with a high level of English proficiency"), instrumentality prevention (e.g., "I have to study English; otherwise, I cannot be successful in my 
future career"), attitudes towards learning English (e.g., "I enjoy learning English"), feared self (e.g., "it will have a negative impact on my life if I do not improve my English"), and English self-concept (e.g., "I am always able to get my ideas across when I write in English"). The internal consistency of these eight subscales reported Cronbach Alpha values that varied between .534 and .822 from pre-test to post-test scores, respectively (table 2).

Self-regulation was examined through 11 items (e.g., "I remember the mistakes my teacher points out to me, and I try not to make them again", "I set my own learning goals, I decide what to learn", "I evaluate my own work, I look at my work to see if it is good or needs improvement"), taken from scales validated in prior self-regulated learning studies (e.g., Iwaniec 2014). The internal consistency of this subscale reported Cronbach Alpha values that varied between .822 and .886 from pre-test to post-test scores, respectively (table 2). Students answered background questions, including age, nationality and age onset of English learning in the final section (Part 3).

Table 2. Internal reliability consistency of the quantitative questionnaire scale items.

\begin{tabular}{|l|c|c|}
\cline { 2 - 3 } \multicolumn{1}{c|}{} & Cronbach Alpha $\boldsymbol{\alpha}$ pre & Cronbach Alpha $\boldsymbol{\alpha}$ post \\
\hline Criterion measures & .615 & .764 \\
\hline Ideal L2 self & .556 & .737 \\
\hline Ought-to self & .610 & .688 \\
\hline Instrumentality Promotion & .645 & .733 \\
\hline Instrumentality Prevention & .627 & .693 \\
\hline Attitudes towards learning English & .662 & .837 \\
\hline The Feared self & .534 & .581 \\
\hline English self-concept & .759 & .692 \\
\hline Self-regulation & .822 & .886 \\
\hline
\end{tabular}

All summative EAP course assessments were included as evaluative tools to ascertain the impact of the intervention on L2 learning outcomes. In total, students were evaluated on 16 tasks submitted during the 6-week course that assessed all EAP modules: a reading and writing module that comprised seven summative assignments (four reading tasks and three writing tasks), a listening and speaking module that contained eight summative assignments (four listening and four speaking tasks), and a research module that consisted of one summative learner-centred research project assignment. Summative assessments were evaluated in accordance with the official EAP marking criteria established by the university. Tasks were marked by the teacher assigned to a group and moderated by the EAP course director and/or manager before a final grade was awarded.

To test L2 possible selves, imagery techniques and ePortfolios within an L2 educational context, the intervention was integrated within the EAP research module, wherein students had to submit an Introduction, Methods, Results and Discussion (IM- 
$\mathrm{RaD}$ ) learner-centred research project assignment, which aimed to compliment and consolidate the reading, writing, listening and speaking modules. The IMRaD project coursebook consisted of six units (one unit per week). To allow for control trials, two versions of the IMRaD project coursebook were designed (see Appendix): a version that integrated the intervention components into the IMRaD course syllabus for the experimental group, and an additional version that excluded these intervention components for the control group. Both control and experimental participants had the same final EAP course objective. Experimental participants were also required to upload each completed component to an ePortfolio, over which they had complete ownership.

The intervention comprised 11 components taken from three dimensions included in Hadfield and Dörnyei's (2013) imagery techniques for L2 possible selves. In brief, when applied to future self-guides (table 3 and Appendix), the first dimension on "imaging identity" served as a brief induction to raise learner awareness on performance forethought and to substantiate L2 vision concerning the present L2 self and desired future L2 self. This dimension included three components: "creating the vision" (component $\mathrm{C} 1$ ), "counterbalancing the vision" $(\mathrm{C} 2)$, and "enhancing the vision" (C4). The second dimension on "mapping the journey" followed on from the work in the induction, establishing short-term and long-term goals, breaking these down into a series of tasks, organising them into a sustainable study plan, making learning contracts and affirming progress. This dimension comprised two components: "personal goal statements, goal breakdown and study plan" (C3) and "from plans to strategies" (C6). The third and last dimension on "keeping the vision alive" was designed to be used in parallel with the goal-setting activities in "mapping the journey", to appeal to the affective as well as the cognitive side, keeping the learner in touch with the initial vision. There were two strands and six components to this dimension: "developing Identity" (C5 and C7), where the aim was to keep in touch with the vision, to develop it in more detail, and make sure it was not lost in the dayto-day business, and "making it real" (C8, C9, C10 and C11), which provided activities that allowed for the use of the L2 in real-life, virtual or simulated situations.

Table 3. Components taken from Hadfield and Dörnyei's (2013) imagery techniques.

\begin{tabular}{|c|c|c|}
\hline DIMENSION I & DIMENSION II & DIMENSION III \\
\hline $\begin{array}{l}\text { Imaging Identity: } \\
\text { short induction to raise } \\
\text { learner awareness and } \\
\text { substantiate the L2 } \\
\text { vision. } \\
\text { Includes three } \\
\text { components: creating } \\
\text { the vision (C1), } \\
\text { counterbalancing } \\
\text { the vision (C2), and } \\
\text { enhancing the vision } \\
\text { (C4). }\end{array}$ & $\begin{array}{l}\text { Mapping the Journey: } \\
\text { substantiating the vision and } \\
\text { setting long-term goals. Includes } \\
\text { establishing short-term goals, } \\
\text { breaking these down into precise } \\
\text { tasks and organising them into } \\
\text { study plans, learning about and } \\
\text { trying out a range of achievement } \\
\text { and avoidance strategies for study, } \\
\text { making learning contracts and } \\
\text { affirming progress. } \\
\text { Comprises two components: } \\
\text { personal goal statements, goal } \\
\text { breakdown and study plan (C3), } \\
\text { and from plans to strategies (C6). }\end{array}$ & $\begin{array}{l}\text { Keeping the Vision Alive: extend } \\
\text { the vision and deepen the L2 } \\
\text { identity. Designed to be used } \\
\text { in parallel with the goal-setting } \\
\text { activities in Mapping the Journey, } \\
\text { to appeal to the affective as well } \\
\text { as the cognitive side, keeping the } \\
\text { learner in touch with the initial } \\
\text { vision. } \\
\text { Includes six components: } \\
\text { developing identity (C5 and C7) } \\
\text { to keep in touch with the vision } \\
\text { and develop it in more detail, and } \\
\text { making it real (C8, C9, C10 and } \\
\text { C11). }\end{array}$ \\
\hline
\end{tabular}


The qualitative data came from 13 semi-guided focus questions inquiring after the reflections of students on the issues under investigation in this study, i.e. L2 motivation, self-regulation and ePortfolios. A total of seven focus groups that comprised 30 students agreed to participate in the focus group interviews. Students were asked to reflect on how they felt about the intervention with questions such as, "Do you think the ePortfolio had a positive or negative effect on your academic performance?" "Which component did you find the most/least useful? Explain." To preserve participants' anonymity, all names have been replaced by numbers for extracts from the focus group interviews. The research design and questionnaire obtained approval from the corresponding Ethics Committee at the university.

\subsection{Data Collection and Analysis}

A six-week intervention study was conducted at the university during the summer EAP programme. A pre-test, post-test, quasi-experimental, comparison group, mixed-methods design was followed. Data collection was conducted on the first day of the EAP course during the student induction (week 1), in which the entire cohort was asked to complete the motivation questionnaire (pre-test measures), and experimental students were asked to set up an electronic portfolio account. On the last day of the course (week 6), all participants again were asked to complete the motivation questionnaire. The IMRaD project module began in week 1 and ended in week 6 . Focus group interviews took place during the last days in week 6 .

Quantitative data obtained were coded and analysed by means of the SPSS 24 programme. Cohorts showed significant pre-existing differences in terms of most L2MSS and self-regulation variables. A new variable was created to report pre and post intervention scores in order to control for these pre-existing differences (i.e. pre-post difference mean). Nonparametric tests were performed to compare L2MSS, self-regulation and L2 acquisition variables, as the test failed normality in some of the cases.

As some students did not submit and complete an integral ePortfolio, a distinction was made to account for the degree of ePortfolio implementation among learners that took part in the intervention. Participants who submitted the intervention in its entirety to their ePortfolio (i.e. all 11 intervention components), adhering to task requirements fully and adequately, formed the ePortfolio complete group $(\mathrm{n}=33$ students). Learners who had not submitted all 11 components to their ePortfolio composed the ePortfolio partial group $(\mathrm{n}=87)$, and learners who were not assigned the intervention remained in the control group $(\mathrm{n}=85)$. As ePortfolio partial and complete participants did not report significant pre-existing differences, variables were compared on both pre-post difference mean scores, followed by a comparison of pre-test and post-test mean scores.

To gauge participants' total proficiency gains, summative assignment grades for each academic skill (writing, reading, speaking and listening) were recorded after each submission in order to calculate whether students' grades increased or decreased cumulatively over the 6-week intervention cumulatively. As the IMRaD research paper was a sole submission, analysis was based on the single final grade awarded.

In order to identify the factors that may have sustained motivation and self-regulation during the intervention or through the use of ePortfolios, semi-structured 
focus group interviews asked experimental participants to reflect on their language learning experience and progress. Qualitative data were a total of 140 minutes, resulting in a corpus made up of 17,041 words. Data were transcribed and analysed using NVivo 10 qualitative analysis software. The procedure of thematic content analysis and constant comparison was employed to search for patterns in the text that ordered the data into categories (Doiz Lasagabaster and Sierra 2014: 121). To this end, discrete ideas expressed by students in each answer (tokens) were identified, these ideas were then classified under the general themes of positive impact and negative impact. Percentages were used as a basis of comparison among themes, categories and subcategories.

\section{Results}

The initial hypothesis was that L 2 possible selves based on imagery strategies and constructed through ePortfolios would serve to increase L2 motivation, self-regulation and language learning outcomes among EAP learners. To test this hypothesis, three types of analyses were conducted. First, findings are presented on the overall effects of the intervention, i.e. upon completion and at the end, on ePortfolio complete and ePortfolio partial participants in comparison to control participants. Second, quantitative data are further examined in relation to the degree of ePortfolio implementation among experimental students, i.e. ePortfolio complete vs. ePortfolio partial learners, based on pre-test and post-test intervention scores from start to finish. Third, qualitative data, garnered from experimental participants on their thoughts about the intervention, are included to expand on quantitative findings and the concepts under scrutiny in this study, i.e. L2 motivation, self-regulation, language learning outcomes and technology.

\subsection{Quantitative Findings}

A one-way between groups analysis of variance (Kruskal-Wallis Test) was conducted to test the impact of ePortfolio implementation. The independent variable was the type of group (control, ePortfolio partial, ePortfolio complete). The dependent variables were the mean difference scores on L2MSS and self-regulation variables calculated from the motivation questionnaire, and mean scores on L2 acquisition variables calculated from the official summative assessments. All these measures were compared once the intervention had been carried out. Analyses only reported significant differences on L2MSS intended learning effort and L2 listening gains (see Figure 1). L2MSS criterion measures showed a significant difference across the three groups $\left(\mathrm{X}^{2}(2, \mathrm{n}=205)=9.76, p=.008\right)$. The ePortfolio complete group recorded an increment $(M=0.67)$, while control $(M=-1.58)$ and ePortfolio partial $(M=-1.25)$ groups reported a diminution. Listening gains also proved to be significantly different across groups $\left(\mathrm{X}^{2}(2, \mathrm{n}=205)=6.65, p\right.$ $=.003)$. Listening means augmented for ePortfolio complete students $(M=2.00)$, whereas means diminished among control $(M=-1.05)$ and ePortfolio partial $(M=$ -.36) participants. 


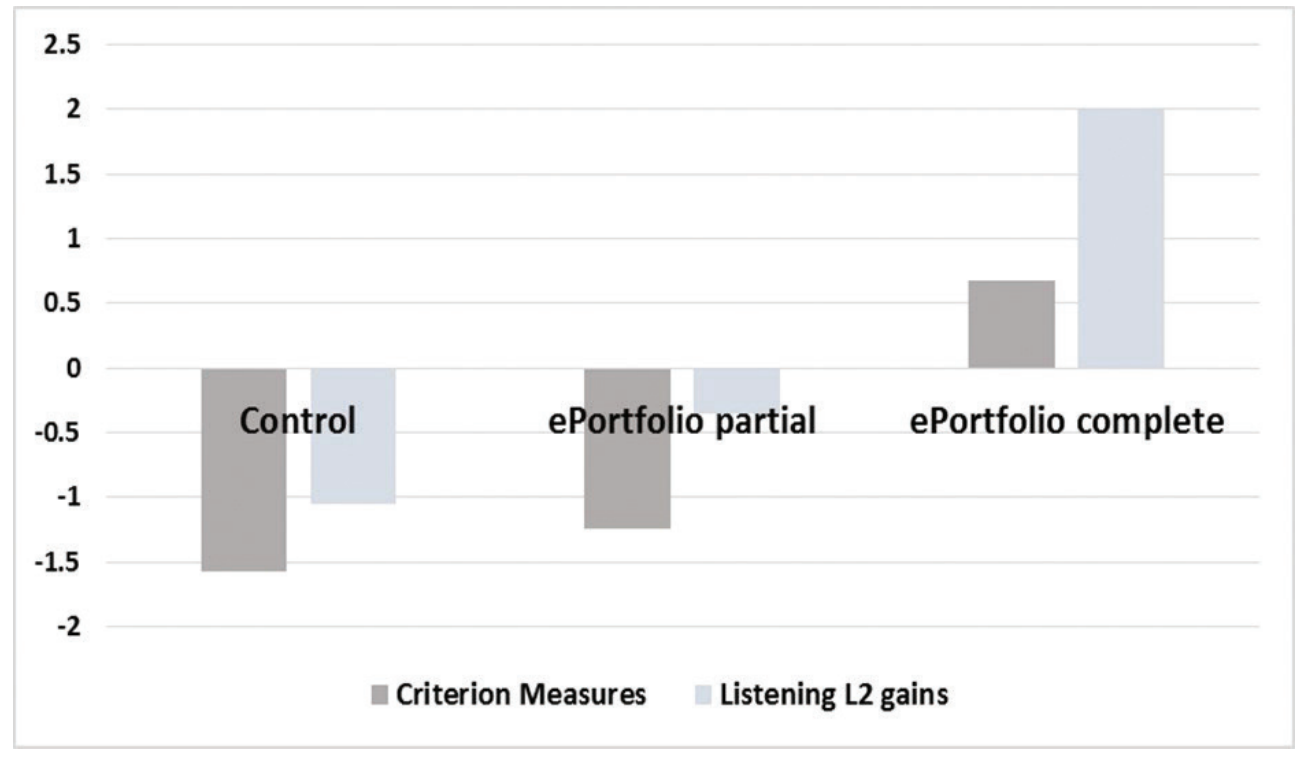

Figure 1. Significant ePortfolio implementation differences on L2MSS criterion measures and listening gains.

Further analyses were performed on ePortfolio partial and ePortfolio complete pre-test and post-test mean scores. A Wilcoxon Matched Pairs Signed Ranks Test on each group revealed a significant decrement from pre-intervention to post-intervention among ePortfolio partial students on L2MSS criterion measures $(z=-2.12$, $p<.03)$, promotion $(z=-2.29, p<.02)$, prevention $(z=-2.52, p<.01)$, attitudes to English $(z=-3.62, p<.00)$ and self-regulation $(z=-2.17, p<.03)$ variables, with a small effect size ( $r=$ between .2 to .4$)$. English self underwent a significant increment from pre- to post-intervention among ePortfolio partial learners $(z=$ $-3.61, p<.00)$, with a small effect size $(r=.4)$. Whereas most measures decreased among ePortfolio partial students, in the case of the ePortfolio complete cohort, the L2 Ideal self significantly improved from pre- to post-intervention $(z=-1.98, p<$ $.04)$, with a small effect size $(r=.4)$. An Independent-Samples Mann-Whitney U Test also revealed L2MSS attitudes to English post-test mean scores as significant among ePortfolio complete students $(z=-2.06, p<.03)$, with a small effect size $(r$ $=.2$ ) (see Figure 2). This means that ePortfolio complete learners significantly held more positive attitudes to English than their partial counterparts upon completing the intervention.

\subsection{Qualitative Findings}

Participants' comments were categorised into three main thematic concepts: motivation, self-regulation and ePortfolios, within which L2 learning was included as a subcategory (see figure 3 and figure 4). In total, the cohort of interviewees was comprised of 18 ePortfolio partial learners and 12 ePortfolio complete learners. The majority of tokens garnered from the ePortfolio complete group displayed greater 


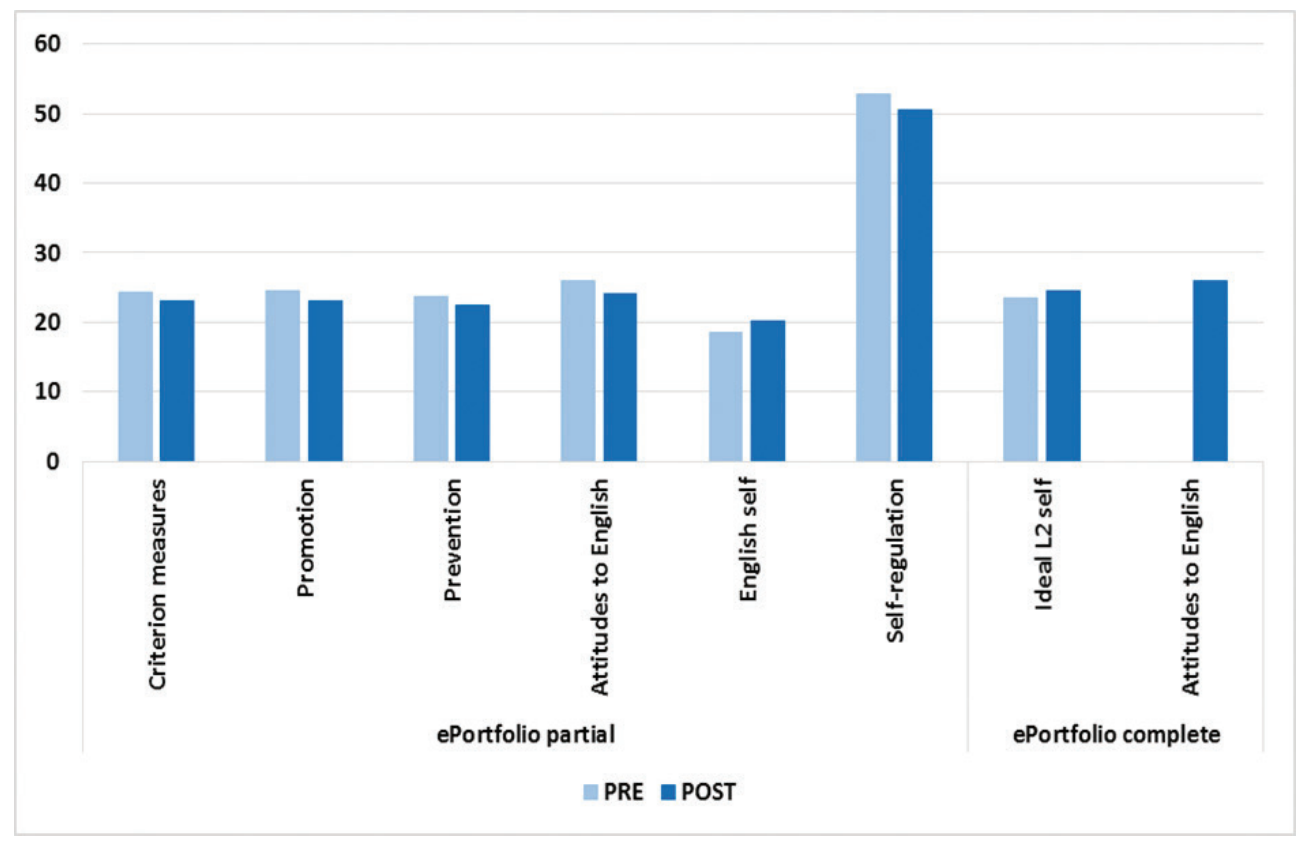

Figure 2. Significant ePortfolio implementation pre-post differences.

optimism on the motivational and ePortfolio benefits offered by the intervention, while they expressed less aversion to self-regulation and the employment of digital technologies.

Tokens categorised under the thematic concept of motivation reported a higher representation among ePortfolio complete participants. Substantial differences between groups on the motivational benefits of the intervention related to development and usefulness. ePortfolio complete students thought the intervention had improved their English skills and general academic competence. An observation that, to a certain degree, was corroborated by their quantitative significant increment in listening proficiency. Interestingly, the majority of ePortfolio complete participants found a listening activity (glossophobia C7) to be the component of most motivational benefit, while ePortfolio partial students mostly identified a writing activity (identity tree $\mathrm{C} 1)$. The following quotes illustrate these subcategories in turn:

The possible self tree [component one] makes me clearly compare me before and when I came to study in the UK. I can see my weakness and things I need to improve in my studies.

(ePortfolio partial, Student 18)

The song because we can listen to some positive songs when we have some free time and improve our vocabulary.

(ePortfolio complete, Student 6)

A higher degree of implementation also appeared to notably heighten students' appreciation of the intervention's utility and convenience, with ePortfolio complete participants expressing greater recognition of the intervention's utilitarian compo- 
nents in the L2 learning process or their academic studies in general. A perception that may have augmented intended learning effort and attitudes to English among these learners, as observed in the quantitative findings, and is exemplified in the following learner's comment:

It's useful because it encourages us to reach our aims and the workload was manageable.

(ePortfolio complete, Student 12)

Contrastingly, participants in the ePortfolio complete group also considered the intervention to have a negative impact on motivation at times, specifically in relation to didacticism, assessment and self-efficacy. Comments offered considered the intervention to have too many writing activities, which created an excessively didactic atmosphere that made the workload burdensome. Indeed, writing components garnered the most tokens within the subcategory of content that had a negative motivational impact, albeit inferior to those made on content that triggered a positive motivational impact by fostering L 2 development. Interestingly, these learners were the only cohort to express that excessively challenging components compromised self-competence and threatened their self-image as an English speaker (self-efficacy). However, concerns related to plausibility were almost twice as high among ePortfolio partial students, who found it difficult to link the intervention to EAP academic objectives and questioned the fact that control participants did not have to complete the intervention. The following quotes illustrate some of the ideas expressed by interviewees on these subcategories:

Because you know for Chinese students this thing is not necessary to do and has no mark or assessment then this is not important and goes to the bottom of my pile.

(ePortfolio complete, Student 13)

Writing the story might be the most difficult for me because I have never read some novels, this was difficult for me so I didn't enjoy it very much.

(ePortfolio complete, Student 7)

Given that ePortfolio complete learners expressed plausibility concerns to a lesser degree, produced a higher amount of tokens on the utility of the intervention, and reported a significant quantitative increment on L2MSS criterion measures, Ideal L2 self and post-test attitudes to English mean scores, it could be inferred that a higher degree of implementation served to cancel opposing forces, which, in turn, maintained motivational equilibrium despite the demands of EAP.

Remarks garnered on the positive impact of the intervention on self-regulation were slightly higher among ePortfolio partial participants, although ePortfolio complete students registered less tokens on the negative impact of the intervention on self-regulation. What is more, ePortfolio complete students registered a higher amount of comments on the intervention's self-regulatory learning benefits as regards mapping strategies, while reporting only half as many tokens on teacher driven dependency. Said differently, learners who had completed the intervention in its entirety appeared to be cognizant of a greater number of mapping strategies, which may have led to less reliance on the teacher and increased self-regulation. An association that may be correlated to these students' quantitative increment on intended 
learning effort (criterion measures). In comparison, ePortfolio partial interviewees connoted the intervention to self-regulatory future strategies and a personal voice in a twofold manner. Such a pronounced appreciation of the intervention's ability to express thoughts in English may have contributed to their significant quantitative increase in English self. Still, the fact that these learners predominantly accredited the intervention to distal goals, i.e. learning English in the future, may have deflected from the utilisation of these strategies on proximal EAP goals. The following quotes illustrate this category accordingly:

The first is because our teacher asked us to do it, and the second because we need to improve ourselves and we can see our weakness so in the future we can see what we do at the time.

(ePortfolio partial, Student 17)

If you review the notes you can improve. I reviewed my presentations from week to week because I need to improve and want to get better. It was helpful.

(ePortfolio complete, Student 14)

Electronic portfolios were the third, and last, thematic construct to be analysed qualitatively. Predominantly, ePortfolio complete participants presented a favourable combination, reporting a higher positive than negative impact, which endorsed the effectivity of ePortfolio implementation. The most mentioned categories being presentations and visuals among this cohort, while ePortfolio partial learners found the evidence aspect (i.e. the fact that the ePortfolio provided a digital record or proof of the work they uploaded) to be of most benefit. To a certain extent, these subcategories were interrelated. Interviewees concurred on the advantages of having a means that evidenced their work and keeping a record of their academic progress. Moreover, interviewees highlighted the practice of self-assessment as fundamental to their L2 learning and progress. The following are quotes that exemplify respondents' thoughts on these categories:

I think we can use this method in the future in our main course we can make our own ePortfolio that keeps a record of all the work we do. This is very useful, because I can make this website a store of knowledge.

(ePortfolio partial, Student 30)

Submitting the presentation because it can show us how to improve what's good and bad. It's useful because our pronunciation is not good and we can improve it and the listening of words we don't know. It was a good feeling when I saw myself. Also, we want to do it better than before. I can see a difference, in my first presentation, I was so nervous, but in presentation three, I'm more relaxed, which makes me feel good. Uploading the presentations and the writing drafts let us improve ourselves.

(ePortfolio complete, Student 24)

The negative impact of ePortfolio technical issues, plausibility, self-efficacy and privacy were minimal among ePortfolio complete interviewees. As a rule, ePortfolio partial learners expressed more technical problems uploading their components to their ePortfolio due to software incompatibilities with mobile phone operating systems. Similarly, they also prompted concerns regarding the privacy of their work and sharing information, as can be observed from the quotes included below. 


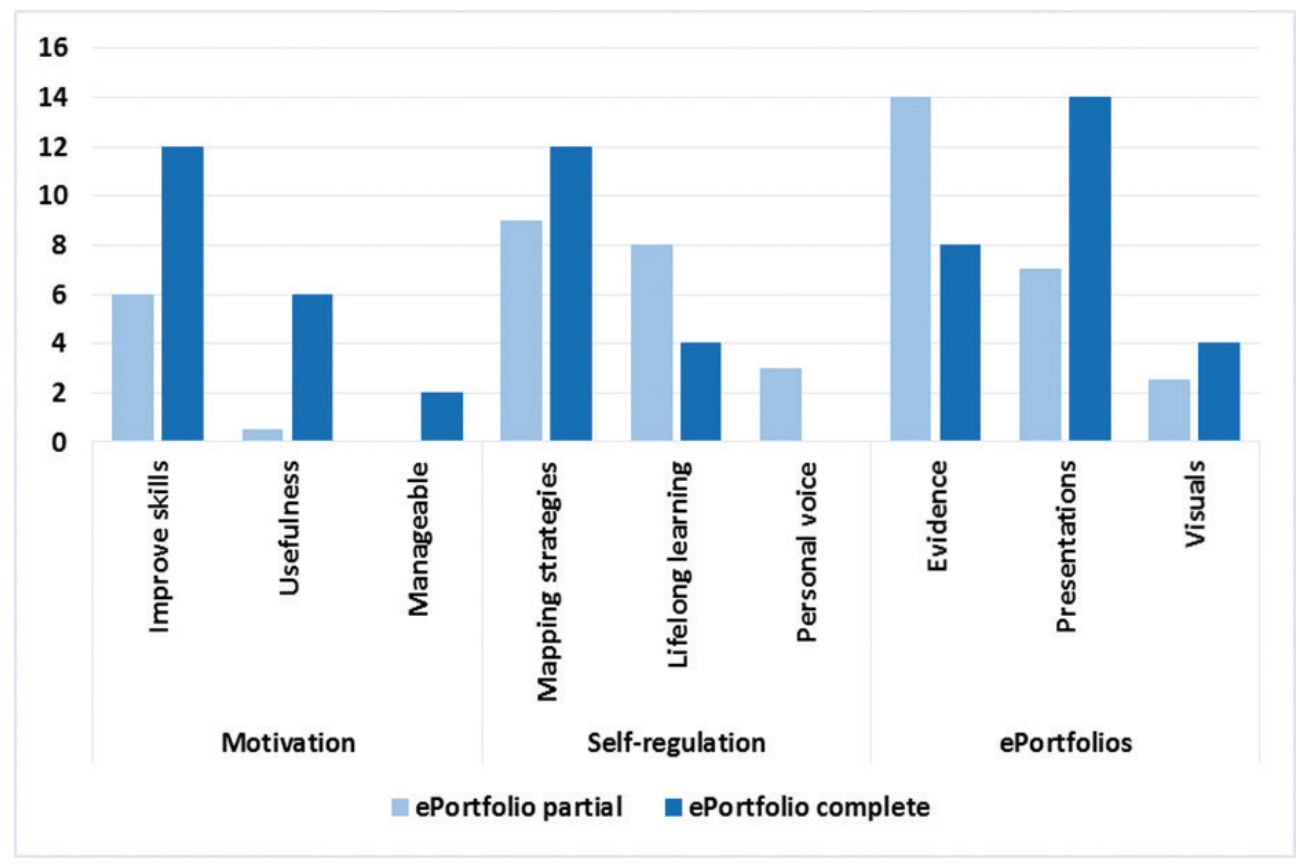

Figure 3. Aspects of the intervention considered to have a positive impact.

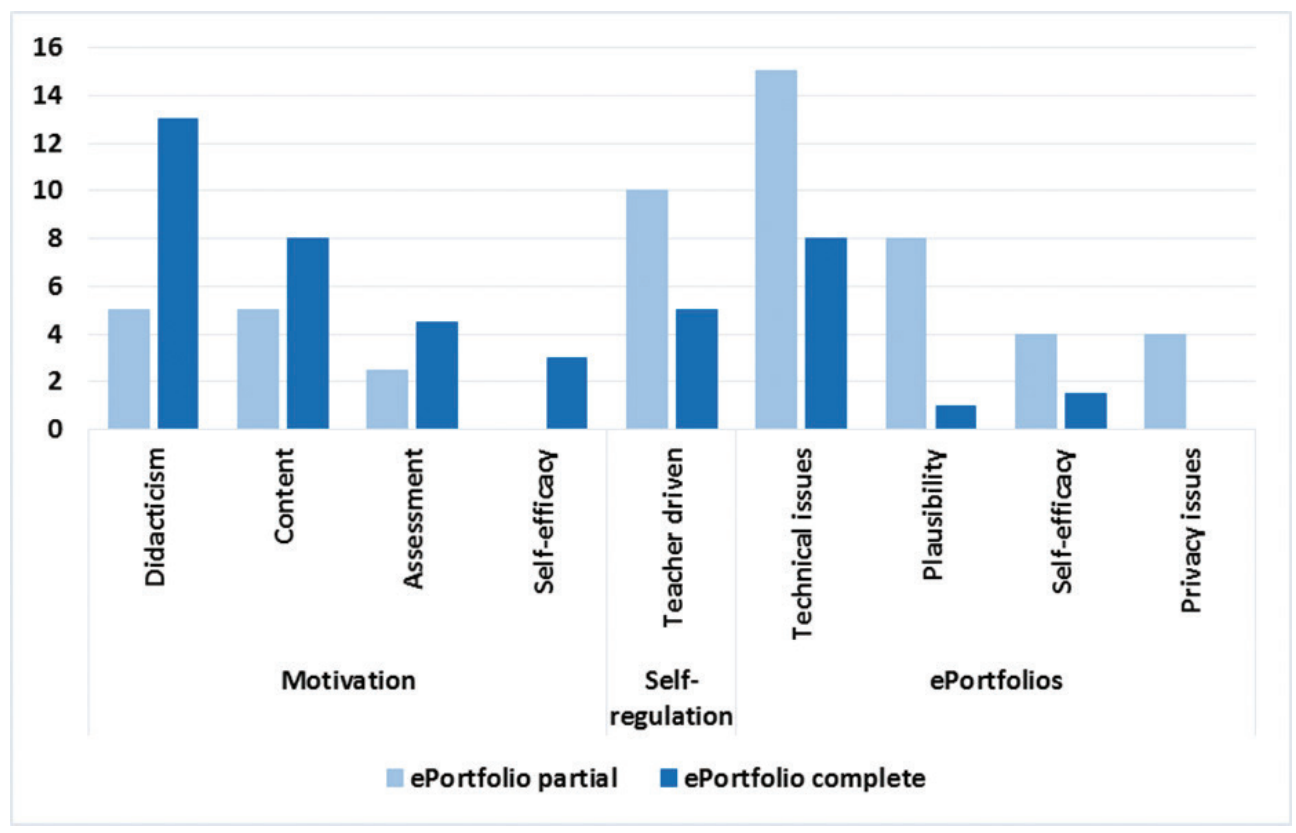

Figure 4. Aspects of the intervention considered to have a negative impact. 
I think the website needs to improve because every time we needed to upload something we had to go to 'Google Drive'. We should be able to do this directly. We need more clear order and title because we couldn't find the clear order, so it was difficult to upload and follow the information.

(ePortfolio partial, Student 30)

I don't know the component, but I'm not good at drawing, so I don't like drawing, and I didn't want to share this information with others.

(ePortfolio partial, Student 3)

\section{Discussion and final conclusions}

One of the main theoretical implications to be drawn from this study is that L2 possible selves based on imagery strategies and constructed through ePortfolios had a positive impact on some aspects of L2 motivation and learning. Experimental students that completed and submitted an ePortfolio in its entirety reported significant progressive gains on L2MSS criterion measures, Ideal L2 self and post-test attitudes to English mean scores. Likewise, ePortfolio complete learners were the only cohort to exhibit a significant melioration in L2 listening gains, in line with qualitative data that underscored a proclivity for listening activities among these students. To a certain degree, these findings endorse the amalgamation of future self-guides, imagery strategies and digital technologies in an L2 educational context.

As per the recommendations in the literature (e.g., Attwell 2007; Barrett 2009; Meyer et al. 2010), ePortfolios served to provide a personal learning environment through which learners could construct L2 possible selves that fostered the development of L2 motivation and proficiency. However, these favourable conditions did not extend to all L2 skills, save listening. An outcome, which may have been due to the brief duration of the intervention (6 weeks), and the reduced amount of students who completed and submitted an ePortfolio in its entirety (33 students). The additional requirements of the intervention and its brief duration may have stymied the effectivity of future self-guides based on imagery techniques through ePortfolios. In spite of these hindrances, ePortfolio complete students still reported a significant improvement in some aspects of motivation and language acquisition, whereas control participants did not register any significant benefits. An ascertainment that adds support to the employment of this type of intervention (e.g., Abrami et al. 2013; Cheng 2008; Magid 2014; Meyer et al. 2010) among EAP learners in higher education.

Our results also support Oyserman et al.'s (2006) claim that L2 possible selves are subject to certain conditions and require more than an imaginary picture of one's desired L2 self. Both quantitative and qualitative findings supported that having a tangible vision of the present and the future had a salient impact on participants' motivation and self-regulation. The ability to engage in self-evaluation and reflect on the components submitted to students' ePortfolios was qualitatively observed as the most notable positive impact throughout the intervention. This visibility allowed students to gauge their present English selves through proximal EAP course objectives in relation to their distal undergraduate learning goals, i.e. Ideal L2 self. This, in turn, constructively permitted students to improve through reflection, self-repair and regulation strategies (Dörnyei 2009; Dörnyei and Ushioda 2009; Ushioda 2014). 
The present study is not without some limitations, the most significant one being the aforementioned low representation of participants who submitted an integral electronic portfolio. This outcome was mainly attributed to restrictions on the length of the course and teaching hours, which may have impeded the effectivity of the intervention and the subsequent imbalanced representation of experimental results. An outcome that may have been further compounded by the fact that intervention components were not graded. Further research in the form of a longitudinal intervention study, which includes summative evaluation, could address the diachronic role of L2 possible selves based on imagery techniques as regards L2 motivation, self-regulation and proficiency through ePortfolios, while it provides a suitable solution to time restrictions experienced throughout the intervention. The fact that the degree of implementation had a positive effect on the results obtained in this study, validates the praxis of this intervention within EAP higher education courses. Notwithstanding, further research is required to validate these findings and to reexamine the role of future self-guides based on imagery techniques through electronic portfolios among a greater sample of students, under the same conditions, in a longitudinal investigation.

\section{References}

Abrami, Philip, Venkatesh, Vivek, Meyer, Elizabeth, and Anne C. Wade (2013). Using electronic portfolios to foster literacy and self-regulated learning skills in elementary students. Journal of Educational Psychology 105(4): 1188-1209.

Asker, Adel (2012). Future self-guides and language learning engagement of English-major secondary school students in Libya: understanding the interplay between possible selves and the L2 learning situation. PhD Thesis, University of Birmingham.

Attwell, Graham (2007). The personal learning environments - The future of eLearning? eLearning Papers 2(1) http://www.elearningeuropa.info/files/media/media11561.pdf Retrieved on 13.12.16.

Barrett, Helen. C (2009). Online personal learning environments: Structuring electronic portfolios for lifelong and life wide learning. On the Horizon 17(2): 142-152.

Cheng, Gary (2008). Implementation challenges of the English language ePortfolio system from various stakeholder perspectives. Journal of Educational Technology Systems 37(1): 97-118.

Dafei, Deng (2007). An exploration of the relationship between learner autonomy and English proficiency. Professional Teaching Articles 1-23.

Doiz, Aintzane, Lasagabaster, David and Juan Manuel Sierra (2014). Giving Voice to the Students. What (de)motivates them in CLIL classes? In Lasagabaster, David, Doiz, Aintzane and Juan Manuel Sierra, eds., 117-138. Dörnyei, Zoltán (2009). The L2 Motivation Self System. In Dörnyei, Zoltán and Ema Ushioda, eds., 9-42.

Dörnyei, Zoltán (2009). The L2 Motivation Self System. In Dörnyei, Zoltán and Ema Ushioda, eds., 9-42.

Dörnyei, Zoltán and Letty Chan (2013). Motivation and vision: an analysis of future L2 self images, sensory styles, and imagery capacity across two TLs. Language Learning 63(3): 437-462.

Dörnyei, Zoltán and Ema Ushioda (2009). Motivation, Language Identity and the L2 Self. Bristol, UK: Multilingual Matters. 
Dörnyei, Zoltán and Ema Ushioda (2011). Teaching and Researching Motivation (2nd ed.). Harlow, UK: Pearson Education.

Hadfield, Jill and Zoltán Dörnyei (2013). Motivating Learning. Harlow: Longman.

Higgins, E Tory (1987). Self-discrepancy: A theory relating self and affect. Psychological Review 94: 319-340.

Hung, Hsiu-Ting (2015). Flipping the classroom for English language learners to foster active learning. Computer Assisted Language Learning 28(1): 81-96.

Iwaniec, Janina (2014). Motivation of pupils from southern Poland to learn English. System 45: $67-78$.

Kim, Yoon-Kyoung and Tae-Young Kim (2011). The effect of Korean secondary school students' perceptual learning styles and Ideal L2 self on motivated L2 behaviour and English proficiency. Korean Journal of English Language and Linguistics 11(1): 21-42.

Magid, Michael (2014). A Motivational Programme for Learners of English: An Application of the L2 Motivational Self System. In Csizér, Kata and Michael Magid, eds., 300-318.

Magid, Michael and Letty Chan (2012). Motivating English learners by helping them visualise their Ideal L2 Self: Lessons from two motivational programmes. Innovation in Language Learning and Teaching 6(2): 113-125.

Markus, Hazel R. and Paula S. Nurius (1986). Possible selves. American Psychologist 41: 954-969.

Meyer, Elizabeth, Abrami, Philip. C., Wade, Anne, Aslan, Ofran, and Louise Deault (2010). Improving literacy and metacognition with electronic portfolios: teaching and learning with ePEARL. Computers \& Education 55: 84-91.

Murray, Garold (2013). Pedagogy of the possible: imagination, autonomy, and space. Studies in Second Language Learning and Teaching 3(3): 377-396.

Oyserman, Daphna, Bybee, Deborah and Kathy Terry (2006). Possible selves and academic outcomes: how and when possible selves impel action. Journal of Personality and Social Psychology 91(1): 188-204.

Sampson, Richard (2012). The language-learning self, self-enhancement activities, and self perceptual change. Language Teaching Research 16(3): 317-335.

Sheldon, Kennon M. and Sonja Lyubomirsky (2006). How to increase and sustain positive emotion: the effects of expressing gratitude and visualising best possible selves. Journal of Positive Psychology 1(2): 73-82.

Taguchi, Tatsuya, Magid, Michael, and Mostafa Papi (2009). The L2 Motivational Self System among Japanese, Chinese, and Iranian Learners of English: A Comparative Study. In Dörnyei, Zoltán and Ema Ushioda, eds., 66-97.

Teng, Lin. Sophie, and Lawrence Jun Zhang (2016). A questionnaire-based validation of multidimensional models of self-regulated learning strategies. The Modern Language Journal 100(3): 674-701.

Ushioda, Ema (2014). Motivation Perspectives on the Self in SLA: A Developmental Perspective. In Mercer, Sarah and Marion Williams, eds., 140-154.

Waller, Laurel, and Mostafa Papi (2017). Motivation and feedback: how implicit theories of intelligence predict L2 writers' motivation and feedback orientation. Journal of Second Language Writing 35: 54-65.

You, Chenjing, and Zoltán Dörnyei (2016). Language learning motivation in China: results of a large-scale stratified survey. Applied Linguistics 37(4): 495-519. 
APPENDIX: EAP IMRaD project course syllabus with and without intervention

\begin{tabular}{|c|c|c|}
\hline & IMRaD Intervention Project & IMRaD no Intervention Project \\
\hline $\begin{array}{l}\text { WEEK } 1 \\
\text { (5 hours) }\end{array}$ & $\begin{array}{l}\text { The value of group work } \\
\text { Teamwork skills and challenges } \\
\text { Primary and Secondary Research } \\
\text { Identity Tree (imaging identity creating the } \\
\text { vision, C1) } \\
\text { Research Questions and Ethics }\end{array}$ & $\begin{array}{l}\text { The value of group work } \\
\text { Teamwork skills and challenges } \\
\text { Primary and Secondary Research } \\
\text { Research Questions and Ethics }\end{array}$ \\
\hline $\begin{array}{l}\text { WEEK } 2 \\
\text { (5 hours) }\end{array}$ & $\begin{array}{l}\text { Methodology overview } \\
\text { Collective effective data: Two Roads poem } \\
\text { (imaging identity, counterbalancing the } \\
\text { vision, C2) } \\
\text { Setting research objectives: personal goal } \\
\text { statements, goal breakdown and study plan } \\
\text { (mapping the journey, from vision to goals } \\
\text { and form goals to plans, C3) } \\
\text { Designing a questionnaire } \\
\text { Asking the right questions: Ideal L2 self } \\
\text { (imaging identity, enhancing the vision, } \\
\text { C4) } \\
\text { Progress presentation methodology section: } \\
\text { giving a presentation (keeping the vision } \\
\text { alive, developing identity, C5) } \\
\text { Report writing draft methodology section: } \\
\text { IMRaD checklist (keeping the vision alive, } \\
\text { role models B, C11) }\end{array}$ & $\begin{array}{l}\text { Methodology overview } \\
\text { Designing a questionnaire } \\
\text { Progress presentation methodology } \\
\text { section (not recorded) } \\
\text { Report writing draft methodology } \\
\text { section (paper format only) }\end{array}$ \\
\hline $\begin{array}{l}\text { WEEK } 3 \\
\text { (5 hours) }\end{array}$ & $\begin{array}{l}\text { Writing introductions } \\
\text { Secondary research skills and table } \\
\text { Presentation skills dos and don'ts } \\
\text { Mini presentation: positive psychology } \\
\text { (mapping the journey, from plans to } \\
\text { strategies, C6) } \\
\text { Developing a voice: glossophobia (keeping } \\
\text { the vision alive, developing identity, C7) } \\
\text { Progress presentation introduction section: } \\
\text { giving a presentation (keeping the vision } \\
\text { alive, developing identity, C5) } \\
\text { Report writing draft introduction section: } \\
\text { IMRaD checklist (keeping the vision alive, } \\
\text { role models B, C11) }\end{array}$ & $\begin{array}{l}\text { Writing introductions } \\
\text { Presentation skills dos and don'ts } \\
\text { Mini presentation: practice vs. } \\
\text { memorisation } \\
\text { Secondary research skills and table } \\
\text { Progress presentation introduction } \\
\text { section (not recorded) } \\
\text { Report writing draft introduction } \\
\text { section (paper format only) }\end{array}$ \\
\hline
\end{tabular}




\begin{tabular}{|l|l|l|}
\cline { 2 - 4 } \multicolumn{1}{c|}{ IMRaD Intervention Project } & \multicolumn{1}{|c|}{ IMRaD no Intervention Project } \\
\hline (5 hours) & $\begin{array}{l}\text { Findings overview } \\
\text { Coding and analysing results } \\
\text { Progress presentation results section: giving } \\
\text { a presentation (keeping the vision alive, } \\
\text { developing identity, C5) } \\
\text { Summarising key findings: learning and } \\
\text { studying abroad (keeping the vision alive, } \\
\text { role models A, C8) } \\
\text { Report writing draft results section: IMRaD } \\
\text { checklist (keeping the vision alive, role } \\
\text { models B, C11) } \\
\text { Discussion overview: limitations and future } \\
\text { research } \\
\text { Academic debate (keeping the vision alive, } \\
\text { virtual guest speaker, C9) }\end{array}$ & $\begin{array}{l}\text { Coding and analysing results } \\
\text { (not recorded) } \\
\text { Report writing draft results section } \\
\text { (paper format only) } \\
\text { Discussion overview: limitations } \\
\text { and future research }\end{array}$ \\
\hline $\begin{array}{l}\text { WEEK 5 } \\
\text { (5 hours) }\end{array}$ & $\begin{array}{l}\text { Analysis and limitations overview } \\
\text { The power of storytelling: cultural events } \\
\text { (keeping the vision alive, entering the L2 } \\
\text { community, C10) } \\
\text { Interpreting research data } \\
\text { Report writing draft discussion section: } \\
\text { IMRaD checklist (keeping the vision alive, } \\
\text { role models B, C11) }\end{array}$ & $\begin{array}{l}\text { Interpreting research data } \\
\text { Report writing draft discussion } \\
\text { section (paper format only) }\end{array}$ \\
\hline WEEKS 1-6 & $\begin{array}{l}\text { Tutorials } \\
\text { Final presentation: giving a presentation } \\
\text { Listening and Speaking module (45 hours) } \\
\text { identity, C5) }\end{array}$ & $\begin{array}{l}\text { Reading and Writing module } \\
\text { (45 hours) } \\
\text { Listening and Speaking module } \\
\text { (45 hours) }\end{array}$ \\
\hline 5 hours) & Final presentation (recorded) \\
\hline
\end{tabular}

